\title{
Portfolio mellem konstruktivisme og instruktivisme
}

\author{
Rasmus Ugilt Holten Jensen, cand.mag.
}

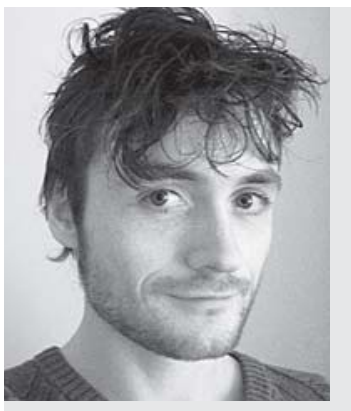

Rasmus Ugilt er cand.mag. i Filosofi fra Aarhus Universitet. Han har været tilknyttet Center for Undervisningsudvikling siden efteråret 2005 - i første omgang som praktikant. Siden hen i forbindelse med div. projekter, såsom konferencen Dialog i Undervisningen, der blev afholdt i foråret 2006. Hans nuværende forskning er orienteret imod spørgsmålet om potentialitet samt forholdet mellem æstetik og politik - han har blandt andet holdt foredrag på London School of Economics med titlen »The Scandalous Autonomy of Art«.

Denne artikel diskuterer forskellige mulige anvendelser af portfolio i undervisnings- og evalueringsøjemed. Den kritiserer den konstruktivistisk inspirerede forskning på området for at arbejde med for snoevert fokus, og for at udelukke en mulig brug af portfolio, som kunne vare frugtbar, selv om den ikke lever op til de konstruktivistiske idealer. Artiklen konkluderes med en skitse over forskellige måder hvorpå en sådan nonkonstruktivistisk brug kunne tage sig ud.

\section{Indledning}

I denne artikel vil jeg diskutere anvendelsen af portfolio som undervisnings- og eksamensform samt den måde, hvorpå man i konstruktivistisk læringsteori anskuer en sådan anvendelse. Det interessante ved den konstruktivistiske tilgang til portfolio er, at den tenderer imod at tage ejerskab over portfolioformen. I megen konstruktivistisk litteratur på området fremstilles portfolio som noget, der udelukkende kan ses som et konstruktivistisk projekt. Dette ønsker jeg at argumentere imod i nærværende, ikke med den pointe at portfolio ikke med fordel kan anvendes $i$ en læringssammenhæng, der er opbygget efter konstruktivistiske principper, men for at bryde den nære forbindelse mellem portfolio og konstruktivisme, og for derved at åbne op for en anvendelse af portfolio, hvor man arbejder med et andet didaktisk grundsyn. Det vil således være min pointe, at portfolio er et nyttigt redskab, som med fordel vil kunne bringes til anvendelse, også hvor undervisningsformen er struktureret efter et mere instruktivistisk ${ }^{1}$ grundsyn. Desuden argumenterer jeg for det syn på portfolio, at der ikke er noget ved redskabet som sådan, der garanterer, at et bestemt læringsmiljø udspringer af dets anvendelse; at man indfører portfolio som eksamens- og undervisningsform garanterer altså ikke, at et godt konstruktivistisk læringsmiljø opstår. Det er brugen det kommer an på.

\section{Hvad er portfolio?}

Portfolio som eksamensform har været kendt igennem længere tid - især på såkaldte kreative uddannelser (kunstakademier, designskoler ol.). I udlandet har man eksperimenteret med at overføre denne eksamensform både til grundskolen og til andre højere uddannelser. Således søsatte man i Vermont i 1988 et statsomspændende forsøg med portfolio som eksamensform i grundskolen (se Koretz et. al., »The Vermont Portfolio Assessment Program: Findings and Implications« 1994), og flere andre steder har man lavet lignende eksperimenter. I Danmark indførtes portfolio som eksamensform pr. 1/8 2005 på Det Humanistiske Fakultet ved Aarhus Universitet, og man diskuterer denne eksamensform i flere andre sammenhænge.

En portfolio er ganske enkelt en mappe, der samler arbejder fra en person med et bestemt formål. Formålet vil typisk kunne inddeles $i$ en af to kategorier: enten samles portfolioen alene for samleren selv, eller også samles den for at blive præsenteret for andre personer. I det øjeblik, der er tale om en eksamensportfolio, er det klart, at der er tale om en portfolio af den sidste type. Imidlertid er det i høj grad muligt at forestille sig en undervisningsportfolio, hvor det ikke er meningen, at den skal præsenteres til en eksamen. En sådan portfolio skulle da blot tjene det formål, at den studerende selv havde sine arbejder samlet på en overskuelig måde, hvilket gør det muligt at reflektere over og måske bedre 
den forståelse, der er udtrykt ved indholdet i portfolioen. En sådan undervisningsportfolio kan sekundært med lethed suppleres af en eksamensportfolio, hvor bestemte arbejder fra undervisningsportfolioen udvælges og samles med præsentation og evaluering for øje.

Med denne brede definition er det klart, at en del forbliver usagt omkring den konkrete implementering af portfolioredskabet. Der er endnu ikke sagt noget om hvilken form en portfolio kan eller bør have. Der er heller ikke sagt noget om, hvorledes portfolio anvendes, eller hvilke konsekvenser indførelsen af portfolio har. Denne åbenhed er væsentlig. Den bliver væsentligere endnu, når man dykker ned i forskningslitteraturen på området.

\section{Konstruktivistisk orienteret forskning i portfolio}

I de senere årtier har man i forskellig litteratur om uddannelse, pædagogik, didaktik, læring osv. kunnet bevidne en overvældende konstruktivistisk bølge. Flere steder taler man om behovet for et paradigmeskifte $i$ den måde, man i praksis tænker om læring (Madsen, 2002, s. 5; Lorentsen, 2002, s. 7; Andersen, 2005, s.10). Forestillingen om nødvendigheden af et sådant paradigmeskifte træder tydeligt i karakter i den konstruktivistisk inspirerede forskning på portfolioområdet. I den konstruktivistiske litteratur (både den teoretiske og den, der tager udgangspunkt i diverse empiriske undersøgelser) ledsages en minimal definition af hvad en portfolio er (som den jeg giver ovenfor) ofte af mere bastante påstande om, hvorledes en portfolio bruges, og hvilke effekter en sådan brug har (eller bør have). Disse effekter er typisk, at den lærende involveres aktivt i egen læring, at den lærende bringes til at reflektere over læringen og læringsformen, eller at den lærende bringes til at deltage aktivt $i$ evalueringen (se Chang 2001a, s. 144, 2001b, s. 435; Wade \& Yarbrough, 1996, s. 63; Smith \& Tillema, 2001, s. 183, 2003, s. 635). Man finder således ofte i litteraturen en antagelse om en forbindelse mellem anvendelsen af portfolio og aktiveringen af klassiske kontruktivistiske dyder. Om end der er ganske mange empiriske studier (se e.g., Chang 2001b; Koretz et al. 1994; Smith, Tillema 2001, 2003; Wade, Yarbrough 1996), der viser hvorledes portfolio med succes kan anvendes i en konstruktivistisk orienteret læringssammenhæng, så er der dog ingen logisk eller nødvendig forbindelse mellem portfolio og konstruktivisme. I særdeleshed synes det problematisk at forestille sig, at man som et direkte resultat af at indføre portfolio som eksamensform, umiddelbart skulle kunne fă et velfungerende konstruktivistisk læringsmiljø.

Et godt eksempel på empirisk og teoretisk forskning med et konstruktivistisk grundsyn, finder man hos Kari Smith og Harm Tillema. I deres »Clarifying different types of portfolio use« (2003) inddeler de forskellige mulige anvendelser af portfolio i fire kategorier efter to dikotomier: (1) Formålet med at konstruere en portfolio kan være konstruktørens egen læring og udvikling i forbindelse med portfoliokonstruktionen, eller også kan portfolioen konstrueres med henblik på udvælgelse, evaluering eller lignende; (2) Portfoliokonstruktionen kan enten være obligatorisk eller frivillig. Ved at forbinde disse to dikotomier får man et skema over de mulige anvendelser af portfolio, som ser således ud (Smith, Tillema 2003, s. 628):

selective (promotion, certification)

\begin{tabular}{cl|l}
\multirow{2}{*}{ Mandated use } & $\begin{array}{l}\text { reflective } \\
\text { portfolio }\end{array}$ \\
\cline { 2 - 3 } & $\begin{array}{l}\text { Training } \\
\text { portfolio }\end{array}$ & $\begin{array}{l}\text { Personal } \\
\text { Development } \\
\text { Portfolio }\end{array}$
\end{tabular}

Learning, developmental purpose

Fig. I

Man kunne her foranlediges til at tro at voluntary/ mandatory-aksen beskriver en glidende overgang, hvor det ene yderpunkt er en portfolioform, der både er obligatorisk med hensyn til form og indhold, og på den måde, at konstruktionen af en portfolio er en obligatorisk del af forløbet. Det andet yderpunkt ville da være en portfolioform, hvor den lærende er frit stillet både med hensyn til om hun vil konstruere en portfolio eller ej og med hensyn til valg af form og indhold. Dette er imidlertid ikke tilfældet. Skellet frivillig/obligatorisk er strengt dikotomisk: enten er portfoliokonstruktionen som sådan frivillig, eller også er portfoliokonstruktionen en obligatorisk del af et forløb. Dermed giver Smith og Tillema i deres beskrivelse af forskellige portfolioformer ikke plads til, at der kan sondres imellem forskellige frihedsgrader med hensyn til formen og indholdet af portfolioen. Dette skyldes at portfoliokonstruktion i deres optik på disse punkter principielt altid er fri. Med hensyn til hvad der kommer i den enkelte studerendes portfolio eller hvilken form den skal have, kan man således nok stille forskellige muligheder til rådighed, men såfremt der stilles eksplicitte krav til hvad en portfolio skal indeholde, begynder man at bevæge sig udenfor det område, Smith og Tillema forstår som egentlig anvendelse af portfolio.

Dermed træder deres konstruktivistiske udgangspunkt med andre ord tydeligt i karakter. For hvis man gjorde det til en legitim anvendelse af portfolio, at underviseren stillede bestemte fordringer til hvad en portfolio skulle indeholde $\mathrm{i}$ forbindelse med et bestemt undervisningsforløb, da ville man hastigt fjerne sig fra det konstruktivistiske paradigme, og i stedet nærme sig en instruktivisme, hvor underviseren fastsætter hvad der skal læres og produceres. Smith og Tillema tager det konstruktivistiske udgangspunkt alvorligt ved 
ganske enkelt ikke at inkludere en sådan anvendelse af portfolio i deres skema over de forskellige mulige portfolioformer. I deres optik er portfolio essentielt et konstruktivistisk redskab og intet andet end det.

\section{Fænomenet washback og en mulig udnyttelse deraf}

Som nævnt argumenterer jeg her for en forståelse af portfolio, som ikke forpligter os til at acceptere den nære forbindelse mellem portfolio og konstruktivismen. Dette sker ikke med den konklusion at en konstruktivistisk anvendelse af portfolio er forfejlet. Målet for argumentationen er blot at gøre det klart, at portfolio bør ses som et redskab, der i sig selv hverken er konstruktivistisk, instruktivistisk eller noget tredje.

Jeg ønsker endvidere at gøre det klart, at portfolio er et redskab, der besidder bestemte kvaliteter, som undervisere med fordel kan trække på, uanset om man arbejder ud fra en konstruktivistisk eller en instruktivistisk grundholdning. Disse kvaliteter finder man især udtrykt ved det fænomen, som Tim Caudery kalder washback (Caudery, 2002, s. 71). Washback bruges som en betegnelse for det forhold, at eksamensformen ofte kommer til at være af afgørende betydning for læringsformen - også selvom undervisningsformen ikke er rettet ind efter det. Fænomenet genkendes let i forbindelse med universitetsundervisning. Hvis man anlægger et undervisningsforløb af to semestres varighed, som har det formål, at de studerende skal skaffe sig en bred og almen viden inden for det emneområde, som kurset omhandler, men samtidig anlægger eksamen som en afsluttende hjemmeopgave, hvor de studerende skal arbejde ud fra et af de gennemgåede delområder, så făr man det resultat, at de studerende set over hele forløbet beskæftiger sig indgående med det ene emne, som de skriver om og kun meget overfladisk med de andre delområder. Washback kendes således som den indflydelse eksamensformen øver på den enkelte studerendes læring. I forbindelse med ovenstående tænkte eksempel kunne man forestille sig at hvert enkelt delområde i det store forløb blev afsluttet med en mindre prøve, som spillede ind i (eller udgjorde hele) den endelige bedømmelse. På den måde kan man benytte frenomenet washback til at få studerende til at lære på en måde, der er mere hensigtsmæssig for det pågældende emneområde, ved at indføre en bestemt eksamensform. John Biggs bruger begrebet 'alignment' om denne positive udnyttelse af frenomenet washback: "A good teaching system aligns teaching method and assessment to the learning activities stated in the objectives, so that all aspects of this system act in accord to support appropriate learning" (Biggs, 2003, s.11).

På dette felt synes portfolio som undervisnings- og eksamensform at have en klar og tydelig styrke. Ved at man definerer portfolio på den minimale måde, som jeg gør ovenfor, kan anvendelsen af dette redskab blive til en effektiv måde at styre washback i en retning, som giver et stort læringsudbytte. Defineres portfolio derimod fra starten som et middel til at højne evnen til selv-refleksion og bevidsthed omkring egen læring hos den lærende (hvor prisværdige sådanne formål end måtte være), da bliver det et redskab med et noget snævrere anvendelighedsområde man står med.

I henhold til ovennævnte eksempel er der for så vidt intet $\mathrm{i}$ vejen for, at en eksamensform, hvor den studerende til bestemte terminer afleverer foruddefinerede opgaver, som underkastes en samlet evaluering ved forløbets afslutning, kaldes for en portfolioeksamen. Og det på trods af, at der ikke synes at være megen fokus på feedback, bevidsthed om egen læring, refleksivitet og så videre i den forbindelse. Der er med andre ord tale om en noget instruktivistisk funderet anvendelse af portfolio som eksamensform. Jeg fremhæver to pointer i denne forbindelse. 1) En sådan anvendelse af portfolio er i høj grad mulig. 2) Set fra et punkt hvor definitionen af portfolio holdes minimal, som jeg gør det ovenfor, er der ikke noget principielt forkert i en sådan anvendelse. Set fra et konstruktivistisk synspunkt er anvendelsen amputeret og problematisk. Men et vigtigt element i nærværende er netop også at gøre op med den nære sammenknytning af portfolio og konstruktivistisk læringsteori. Dermed skal det ikke være sagt, at en anvendelse af portfolio, som har det formål at gøre den lærende mere bevidst om egen læring eller lignende, i denne optik pludselig bliver illegitim. Blot er det en væsentlig pointe her, at der da er tale om en bestemt form for anvendelse af et redskab, som også kan anvendes på en række andre måder. Der er med andre ord intet ved redskabet som sådan, der garanterer at brugen af det vil medføre, at et godt læringsmiljø (i konstruktivistisk forstand) opstår.

Her finder vi endnu en grund til at gøre op med den nære sammenknytning af portfolio og konstruktivisme. Hvis portfolio forstås som et redskab, der grundlæggende er konstruktivistisk, så ligger den tanke let for, at man alene ved at indføre portfolio som eksamens- og undervisningsform kan frembringe og dyrke et konstruktivistisk læringsmiljø. Dette ville være en misforståelse af en art, hvor man forvekslede redskabet med arbejdet. Ganske som det ikke er hammeren der gør arbejdet med at slå sømmene i (men derimod tømreren), er det heller ikke portfolioen, der gør arbejdet med at fă et konstruktivistisk læringsmiljø til at opstå, men derimod dem der bruger den (studerende og undervisere). Som med de fleste andre redskaber er det brugen, der bestemmer det udbytte, man får af portfolio.

\section{Konklusion: Portfolio som middel til et mål}

Når det er sagt at portfolio bør forstås som et redskab, er det endvidere en vigtig pointe, at portfolio 
dermed aldrig kan (bør) blive et mål i sig selv, men derimod altid må forstås som et middel til at nå et mål. Judith Fueyo beskriver i sin artikel "»What Do You Really Care about Here? «: Portfolios as Rites of Passage« (1996) nogle af de problemer, der meget let kan opstå, når portfolio bliver til et mål i sig selv. Hun beskriver sine frustrationer over ikke på nogen måde at have mulighed for at sætte sig ind i, forstå og vurdere de enorme produktioner, portfolioer kan ende med at blive, når der ikke er faste rammer for portfoliokonstruktionen. Hun beskriver konstruktionsprocesser, som i sig selv måske har været interessante nok for konstruktøren, men som i sidste ende har været en kilde til frustration både for denne og for bedømmeren/underviseren, netop fordi hver enkelt portfolio ender med at lukke sig om sig selv. Portfolioen kommer således til repræsentere en verden i sig selv, der ikke kan bringes i forbindelse med noget andet. Dermed står den lærende med det frustrerende resultat at have brugt en mængde energi på at konstruere noget, som ikke rigtig synes at føre nogen vegne og underviseren/bedømmeren står med den uoverkommelige opgave at skulle sætte sig ind i og forstå de ofte voluminøse produktioner, som portfolioerne udgør. Fueyo beskriver hvorledes selve opbevaringen af portfolioerne ofte udgjorde et problem i sig selv: kasser og mapper med papir hobede sig op i stakke både på - og i gangen uden for - hendes kontor. Det er klart at overgangen til en elektronisk portfolioform måske ville kunne løse det logistiske problem i denne forbindelse, men dermed ville man stadigvæk stå med det hermeneutiske problem med at sætte sig ind i og forstå sådanne gigantiske produktioner.

Den pointe man bør trække ud af Fueyos case er klar. Hvad der fordres er en bevidsthed om formålet med anvendelsen af portfolio i undervisningen. Med en sådan bevidsthed er det muligt at bringe portfolioredskabet til anvendelse på lige netop den måde, der passer bedst til den læringsgenstand, som gives for det enkelte forløb. Jeg nævner her tre mulige formål, som alle med fordel vil kunne forfølges ved hjælp af portfolioredskabet. 1) Tilegnelse af viden på en rakke klart definerede områder. Som det blev nævnt ovenfor, er det en helt igennem legitim (instruktivistisk) anvendelse af portfolio at give bestemte opgaver til de studerende, som skal besvares til bestemte tidspunkter i løbet af et undervisningsforløb, for at samle disse (i en portfolio) og give dem en samlet bedømmelse (evt. via udvælgelse af dele af materialet) til slut i forløbet. Hvor formålet med et forløb er, at de studerende skal indoptage så megen generel viden som muligt på forskellige delområder, der alle dækkes af forløbet, vil en sådan anvendelse af portfolio kunne virke glimrende. 2) Tilegnelse af bestemte kvalifikationer eller kompetencer. Hvor et undervisningsforløb er lagt an på, at de lærende skal tilegne sig nogle bestemte færdigheder, vil portfolio igen kunne bringes til anvendelse på en fornuftig måde. Her vil den enkelte studerende typisk skulle levere produkter, som afspejler de kompetencer, hun forventes at tilegne sig i forløbet, til portfolioen. I en sådan forbindelse vil det begynde at give mening, at de studerende har adgang til deres egen portfolio. For derved vil de kunne gennemgå de produkter, de tidligere har leveret, og derved få en bedre forståelse for deres egen produktion. De vil have mulighed for selv at identificere styrker og svagheder og dermed have mulighed for at træne de relevante områder. ${ }^{2}$ Eksempelvis vil man $i$ et sprogundervisningsforløb, hvor man sigter imod at hjælpe de studerende til at få en bedre udtale, med fordel kunne opbygge en elektronisk portfolio med optagelser af de studerende. Aflytning af disse optagelser og kommentering fra underviser og medstuderende vil derefter med fordel kunne integreres i undervisningen. 3) Opøvelse af refleksivitet omkring egne evner og kompetencer. Dette er et af de formål, man oftest støder på i litteraturen omkring portfolio. Og det er da også klart, at det er muligt at bringe portfolio til anvendelse på en måde, så de studerende hjælpes til at få en bedre forståelse for deres egen læring. Her vil det begynde at give mening at bede de studerende om selv at bedømme, hvad indholdet af deres egen portfolio skal være (hvilket i en optik, som vi eksempelvis finder hos Smith og Tillema, er en forudsæetning for at vi kan tale om egentlig portfolio). Man kunne for eksempel få dem til at komme de produkter i portfolioen, som de selv synes giver den bedste afspejling af de kompetencer, som de har opnået igennem forløbet. Derudover kunne det kræves, at portfolioen også skulle indeholde en begrundelse for, hvorfor det netop var de produkter og ikke alle mulige andre den studerende valgte ud.

Pointen med denne korte opstilling af forskellige mulige formål med anvendelsen af portfolio i undervisnings- og evalueringsøjemed er at gøre det klart, at de alle er mulige og legitime formål. De forskellige anvendelsesformer, jeg nævner her, giver endvidere et billede af, hvorledes portfolio kan anvendes på vidt forskellige måder. Portfolio kan ikke ses udelukkende som et middel til at gøre de studerende mere aktive $i$ deres egen læring. Portfolio kan lige så vel anvendes $i$ forbindelse med en undervisningsform, der (i høj grad) er forelæsningsbaseret. Dette betyder endvidere også, at man ikke må betragte portfolio som et vidundermiddel, man kan bringe $\mathrm{i}$ anvendelse med det resultat, at et godt konstruktivistisk læringsmiljø opstår af sig selv. Portfolio er et redskab, og som med alle andre redskaber er det $\mathrm{i}$ forbindelse med portfolio den konkrete anvendelse, der er udslagsgivende.

\section{Litteratur}

Andersen, Hanne Leth (2005), Eksamensformer:Valg med konsekvenser, i serien Arbejdspapirer fra Center for Undervisningsudvikling, Humanistisk Fakultet, Aarhus Universitet.

Biggs, John (2003), Teaching for Quality learning at University, Open University Press, Buckingham and Philadelphia. 
Caudery, Tim (2002), "Portfolios - electronic or otherwise - as a basis for assessment«, i Læreprocesser og IT.Virtuel portfolio i undervisningen, udgivet af IT Indsatsen ved Aalborg Universitet i samarbejde med Viborg Amt og FUIP - Forsknings- og Udviklingscenter for IKT-pædagogik, Skive, s. 62-73.

Chang, Chi-Cheng (2001a), "Construction and Evaluation of a Web-Based Learning Portfolio System: An Electronic Assessment Tool", i Innovations in Education and Teaching International, Volume 38, Nomber 2/May 1, s. 144-155.

Chang Chi-Cheng (2001b), "A study on the evaluation and effectiveness analysis of web-based learning portfolio (WBPL) «, i British Journal of Education Technology, Vol 38, no 4, s. 435458.

Fueyo Judtih (1996), » What Do You Really Care about Here?«: Portfolios as Rites of Passage«, i Fogarty (ed.) (1996), Student Portfolios, A Collection of Articles, Skylight Training and Publishing inc., Arlington Heights, Illinois.

Hertel, Frederik og Madsen, Svend (2002), "Indledning«, i Læreprocesser og IT.Virtuel portfolio i undervisningen, udgivet af IT Indsatsen ved Aalborg Universitet i samarbejde med Viborg Amt og FUIP - Forsknings- og Udviklingscenter for IKTpædagogik, Skive, s. 5.

Koretz, Daniel, Stecher, Brian, Klein, Stephen, and McCaffrey, Daniel (1994), "The Vermont Portfolio Assessment Program: Findings and Implications", i Educational Measurement: Issues and Practice, Fall 1994, s 5-16.

Lorentsen, Annette (2002), »Om forandringen af læreprocesser og læremiljøer, når læringen er It-støttet", i Læreprocesser og IT. Virtuel portfolio i undervisningen, udgivet af IT Indsatsen ved Aalborg Universitet i samarbejde med Viborg Amt og FUIP - Forsknings- og Udviklingscenter for IKT-pædagogik, Skive, s. 6-27
Smith, Kari og Tillema, Harm (2001), »Long-term Influences af Portfolio on Professional Development", i Scandinavian Journal of Educational Research, Vol. 45, no. 2, s. 183-203.

Smith, Kari og Tillema, Harm (2003), »Clarifying different types of portfolio use", i Assessment and Evaluation in Higher Education, Vol. 28, no. 6, Dec 2003, s. 625-648.

Tillema, Harm og Smith, Kari (2000), „Learning from Portfolios: Differential use of Feedback in Portfolio Construction«, i Studies in Educational Evaluation 26, s. 193-210.

Wade, Rahima, Yarbrough, Daniel (1996), »Portfolios: A tool for reflective thinking in teacher education?«, $\mathrm{i} \quad$ Teaching and Teacher Education, Vol 12, No 1, s. 63-79

\section{Noter}

1 Jeg kommer i denne artikel ikke nærmere ind på forholdet mellem konstruktivisme og instruktivisme (positivisme). Dette til trods for, at jeg finder denne diskussion særdeles interessant og væsentlig. Der bør dog gives en definition af begreberne, som jeg benytter dem her. Instruktivisme forstås i nærværende som den teoretiske grundindstilling, der hævder, at den primære aktivitet $\mathrm{i}$ en undervisningssituation ligger hos underviseren. Modsat hævdes det i konstruktivismen, at den primære aktivitet bør ligge hos den lærende.

2 I første omgang er det kun sagt, at det er muligt for de studerende at gøre en sådan brug af portfolioen. Aktualiseringen af dette potentiale er ikke nogen direkte følge. Det vil i reglen kræve, at denne anvendelse af portfolioen integreres som en del af undervisningen (igen i den ovenstående definition), for at muligheden udnyttes til fulde. 